\title{
ANALYSIS OF A HIGH-PIER RAILWAY BRIDGE UNDER SPATIAL STOCHASTIC STATIONARY AND NON-STATIONARY EARTHQUAKE EXCITATIONS
}

\author{
Jin Zhang, Hongyu Jia, Shixiong Zheng, Shiqiang Qin, Keyue Zhang
}

Original scientific paper

The objectives of this paper are to perform a comparative analysis of the large-scale system of a high-pier railway bridge subjected to stationary and nonstationary spatially varying earthquake excitations using the pseudo-excitation method (PEM), and to estimate whether or not the non-stationary stochastic analysis of the high-pier railway bridges under tri-directional spatial ground motions can be simplified into a stationary random analysis to avoid excessive computation. Based on the finite element software ANSYS, the stationary and non-stationary stochastic excitations analyses of a high-pier bridge were transformed into harmonic analyses and deterministic transient analyses in the study, respectively, by using PEM. The wave-passage effect and the incoherence effect were modelled as the key factors, a total of twelve cases were considered to investigate the wave-passage effect and incoherence effect on the seismic response of a high-pier railway bridge under stationary and non-stationary earthquake excitations. Results show that structural responses under stationary excitation are larger than those under non-stationary by considering either the wave-passage effect or the incoherence effect. Through comparing structural responses under stationary excitation with those under non-stationary one, all the growth rates are less than $25 \%$, which is acceptable in engineering, meaning that a non-stationary stochastic analysis of high-pier railway bridges under tri-directional spatial ground motions can be simplified into a stationary analysis to avoid excessive computation.

Keywords: high-pier railway bridge; incoherence effect; non-stationary stochastic excitation; pseudo-excitation method; wave-passage effect

\section{Analiza željezničkog mosta na visokim stupovima pod prostornim stohastičkim stacionarnim i ne-stacionarnim uzbudama potresa}

Izvorni znanstveni članak Ciljevi ovoga rada su provesti komparativnu analizu velikog sustava željezničkog mosta na visokim stupovima izloženog stacionarnim i ne-stacionarnim prostorno promjenjivim uzbudama potresa primjenom metode pseudo-uzbude (pseudo-excitation method - PEM), te procijeniti može li se ili ne može nestacionarna stohastička analiza željezničkih mostova na visokim stupovima izloženih trosmjernim prostornim podzemnim gibanjima zamijeniti jednostavnijom stacionarnom slučajnom analizom kako bi se izbjegla prekomjerna računanja. Zasnovane na ANSYS softveru konačnih elemenata, analize stacionarnih i ne-stacionarnih stohastičkih uzbuda mosta na visokim stupovima pretvorile su se u harmonične analize i determinističke prijelazne analize u našem istraživanju, primjenom PEM-a. Učinak prolaza vala i učinak nekoherentnosti modelirani su kao ključni čimbenici, a ukupno je razmotreno dvanaest slučajeva u svrhu ispitivanja učinka prolaza vala i učinka nekoherentnosti na seizmičku reakciju željezničkog mosta na visokim stupovima izloženog stacionarnim i ne-stacionarnim uzbudana potresa. Rezultati pokazuju da je reakcija konstrukcije pod stacionarnom uzbudom veća nego kod nestacionarne uzimajući u obzir bilo učinak prolaza vala ili učinak nekoherencije. Kad se uspoređuju reakcije konstrukcije pod stacionarnom pobudom s onima kod ne-stacionarne, sve stope rasta su manje od $25 \%$, što je u tehnici prihvatljivo, a to znači da se ne-stacionarna stohastička analiza željezničkih mostova na visokim stupovima pri trosmjernim prostornim gibanjima u zemlji može pojednostavniti $u$ stacionarnu analizu kako bi se izbjeglo prekomjerno računanje.

Ključne riječi: metoda pseudo-uzbude; ne-stacionarna stohastička uzbuda; učinak nekoherencije; učinak prolaza vala; željeznički most na visokim stupovima

\section{Introduction}

In recent years, many high-pier railway bridges have been constructed in Chinese southwestern regions due to rapid economic development and the area's mountainous site topography [1]. According to statistics on Chinese high-pier railway bridges, around $90 \%$ of these bridges are in the west of China, and approximately $40 \%$ of them have piers higher than $40 \mathrm{~m}$. Furthermore, these mountainous railway bridges with piers of varying heights usually have continuous and rigid frame girders in the superstructure and thin-walled hollow piers. Most of these bridges in western area of China exceed specification requirements and are different from highway bridges with relatively flexible main girders [2]. On the other hand, the southwest area of China, where these railway bridges are located, is a dense seismic zone (e.g., the 2008 Wenchuan Earthquake occurred on May 12, 2008 in Sichuan province with an earthquake magnitude 8,0 , and the Lushan Earthquake on April 20, 2013, also in Sichuan province, with an earthquake magnitude 7,0) [3]. Meanwhile, almost all high-pier railway bridges built in maintainous area, such as the span lengths and pier heights, are beyond the range of seismic design codes [4].
Moreover, the seismic performance of high-pier railway bridges may be significantly different from highway or pedestrian bridges according to their special structural configurations and varying complex gully site conditions. For instance, the high-pier railway bridges in the substructure usually have high yet flexible piers, while the girders in the superstructure are often required to be more rigid in order to avoid derailment of high-speed trains and the excessive vertical deflection caused by rail loads. Consequently, this has shed light on the importance and necessity of seismic analysis and the design of high-pier railway bridges in the southwestern regions of China [5, 6]. Therefore, it is of great importance to study the seismic performance of high-pier railway bridges for realworld applications of seismic design and analysis for high-pier railway bridges.

Because of random characteristic of earthquakes in nature, the random vibration method (RVM) is widely used and accepted in seismic analysis of long-span structures and has been adopted by several seismic design standards $[7 \div 9]$. Because the RVM requires extensive computation for the seismic analysis of high-pier railway bridges under tri-directional stochastic excitations, the pseudo-excitation method (PEM), proposed by Lin and 
also known as the fast complete quadratic combination method [10], was adopted in this paper to render the stochastic computation more efficient. The stationary stochastic excitation analyses and the non-stationary stochastic excitation analyses of structural systems with a large number of degrees of freedom and dozens of supports are then transformed, respectively and exactly, into harmonic analyses and deterministic transient ones using PEM to avoid multiple integral operations. Hence, PEM is a promising tool in the stochastic analysis of complex yet significant structures, and it was selected in this paper for the random analysis of a high-pier railway bridge under tri-directional seismic excitations.

In the current study, many researchers have studied the seismic response of structures under stationary and non-stationary random excitations, and corresponding research results have been achieved $[11 \div 13]$. As evident from the previous studies, structural responses under nonstationary excitation are more complicated and time consuming than structural responses under stationary excitation. But it is unclear how much its accuracy has improved. Few references on the seismic response difference analysis using two excitation types can be found. Hence, for a practical engineering application, the objectives of this paper are to perform a comparative analysis of a high-pier railway bridge subjected to spatially varying stochastic stationary and non-stationary earthquake excitations using PEM, and then to estimate whether or not the non-stationary stochastic analysis of high-pier railway bridges under tri-directional spatial ground motions can be simplified to a stationary random analysis to avoid extensive computation. The seismic design of large span bridges requires accounting for the spatial variability of the ground motion. The spatial variability of ground motions is caused by three phenomena: (a) the incoherence effect; (b) the wavepassage effect; and (c) the differential site-response effect $[14,15]$. Jia and Zhang [16, 17] did work on seismic response analysis regarding site effects of long-span rigid frame bridges in mountainous areas. Jia presented a theoretical non-stationary stochastic analysis scheme that uses the pseudo-excitation method (PEM) for the seismic analysis of long-span structures under tri-directional spatially varying ground motions, based on the local site effects on structural seismic response, which were studied in regard to a high-pier railway bridge. Zhang proposed an improved high precision direct integration method (IHPDIM) and an absolute-response-oriented scheme of the pseudo-excitation method (PEM) for the non-stationary stochastic seismic analysis of large structures. According to the reference [16], the basic site combination consists of the most unfavorable conditions in which the high piers are in the soft ground and the other piers are in firm ground. In view of this, this paper calculates the stationary and non-stationary response of the bridge structure, taking into account the wave-passage effect and the incoherence effect.

Following the above discussions, this paper is to present a theoretical random vibration analysis for a highpier railway bridge including the stationary seismic excitations and the non-stationary seismic excitations, and their comparison analysis by PEM. Section 2 of this paper introduces the derived theoretical basis of PEM for structural seismic analyses. Numerical analyses are conducted in section 3 for seismic evaluations of a highpier railway bridge considering effects of stationary and non-stationary tri-directional seismic excitations through proposed cases. Concrete results are presented in section 4 and four conclusions and observations are drawn in section 5 .

\section{Theoretical basis}

\subsection{PEM in seismic analysis of structures subjected to tri- directional seismic excitations}

The equations of motion for a discretized linear, ndegree-of freedom structural system subjected to $\mathrm{m}$ directional support motions (three translational components) can be written in the partitioned matrix form in the global coordinate system as [18]:

$\left[\begin{array}{cc}M_{s s} & M_{s b} \\ M_{b s} & M_{b b}\end{array}\right]\left\{\begin{array}{c}\ddot{X}_{s} \\ \ddot{X}_{s}\end{array}\right\}+\left[\begin{array}{cc}C_{s s} & C_{s b} \\ C_{b s} & C_{b b}\end{array}\right]\left\{\begin{array}{c}\dot{X}_{s} \\ \dot{X}_{s}\end{array}\right\}+\left[\begin{array}{cc}K_{s s} & K_{s b} \\ K_{b s} & K_{b b}\end{array}\right]\left\{\begin{array}{c}X_{s} \\ X_{s}\end{array}\right\}=\left\{\begin{array}{c}0 \\ P_{b}\end{array}\right\}$

in which vector $\left\{X_{b}\right\}_{3 \times m}=\left\{X_{1}, X_{1}, \ldots, X_{3 \times m}\right\}^{T}$ represents the enforced displacements of $m$ supports, $\left\{X_{s}\right\}_{3 \times n}=\left\{X_{1}, X_{1}, \ldots, X_{3 \times n}\right\}^{T}$ denotes the vector of absolute displacements of the slave degrees of freedom (DoFs), and $\left\{P_{b}\right\}_{3 \times m}=\left\{P_{1}, \mathrm{P}_{1}, \ldots, \mathrm{P}_{3 \times m}\right\}^{T}$ is the vector of seismic forces at structural supports. $M, C$ and $K$ are the mass, damping, and stiffness matrices, respectively. The subscripts $\mathrm{b}$ and $\mathrm{s}$ refer to the master and slave DoFs, respectively. $M_{b s}, C_{b s}$, and $K_{b s}$ denote the transpose of matrix $M_{s b}, C_{s b}$, and $K_{s b}$, respectively. The lumped mass model is assumed in this paper, i.e., $M_{s b}$ is null. The vector of seismic forces $P_{b}$ can be expressed in terms of the mass of supports $M_{b b}$ and the ground acceleration $\ddot{u}_{b}$ as $P_{b}=M_{b b} \cdot \ddot{u}_{b}$.

Then, the large mass method was used to get absolute displacement values of structure, the large mass $M_{b b}$ are usually selected between $10^{5}$ and $10^{8}$ times the structural total weights for an acceptable approximation of structural seismic responses.

According to the reference [16], the power spectral density of absolute displacement $\tilde{X}_{S}(\omega, t)$ can be:

$S_{X_{s} X_{s}}(\omega, t)=\tilde{X}_{s}^{*}(\omega, t) \tilde{X}_{s}^{T}(\omega, t)$

$\tilde{X}_{S}(\omega, t)$-Absolute displacement, and superscripts * and $\mathrm{T}$ denote the complex conjugate and the transpose.

\subsection{Modeling of tri-directional spatially varying ground motions and determination of pseudo excitation forces}

By ignoring the time variable $t$, the non-stationary RVM becomes a stationary RVM. Hence, the following non-stationary RVM is presented alone, because of limited space.

The cross-power spectral density function of tridirectional non-stationary spatially varying ground motions at $\mathrm{m}$ spatial points can be expressed as: 


$$
S_{0}[(i w, t)]=\left[\begin{array}{ccccc}
S_{11}(i w, t) & S_{12}(i w, t) & S_{13}(i w, t) & \cdots & S_{1 m}(i w, t) \\
S_{21}(i w, t) & S_{22}(i w, t) & S_{23}(i w, t) & \cdots & S_{2 m}(i w, t) \\
S_{31}(i w, t) & S_{32}(i w, t) & S_{33}(i w, t) & \cdots & S_{3 m}(i w, t) \\
\vdots & \vdots & \vdots & \ddots & \vdots \\
S_{m 1}(i w, t) & S_{m 2}(i w, t) & S_{m 3}(i w, t) & \cdots & S_{m m}(i w, t)
\end{array}\right]
$$

where each sub-matrix element $S_{k l}(i w, t)$ is a $3 \times 3$ matrix, corresponding to two horizontal components $(x, y)$ and one vertical component $(z)$ of tri-directional ground motions, and is given by:

$$
S_{k l}(i w, t)=\left[\begin{array}{lll}
S_{k l x x}(i w, t) & S_{k l x y}(i w, t) & S_{k l x z}(i w, t) \\
S_{k l y x}(i w, t) & S_{k l y y}(i w, t) & S_{k l y z}(i w, t) \\
S_{k l z x}(i w, t) & S_{k l z y}(i w, t) & S_{k l z z}(i w, t)
\end{array}\right] .
$$

The power spectral density functions of the tridirectional ground motion horizontal components are assumed to be the same, and the correlation coefficients between the horizontal components and vertical component are assumed to be 0,6 [19]. Hence, they are given by:

$$
\begin{aligned}
& S_{k l x z}(i w, t)=S_{k l y z}(i w, t)=0.6 \sqrt{S_{k l x x}(i w, t) S_{k l z z}(i w, t)}= \\
& 0.6 \sqrt{S_{k l y y}(i w, t) S_{k l z z}(i w, t)}
\end{aligned}
$$

Based on the theory of the evolutionary power spectrum for non-stationary stochastic processes, elements of the cross-spectral density matrix are defined as:

$$
S_{k l x x}(i w, t)=\left\{\begin{array}{lr}
G_{k k x x}(t) G_{l l k x}(t) \sqrt{S_{k k x x}(\mathrm{i} \omega) \mathrm{S}_{l l k x}(\mathrm{i} \omega)} \rho_{k l x x}(\mathrm{i} \omega), \mathrm{k} \neq 1 \\
\left|G_{k k k x}(t)\right|^{2} S_{k k x x}(\mathrm{i} \omega), & k=1
\end{array}\right.
$$

where $G_{k k x}(t)$ and $S_{k k x}(\mathrm{i} \omega)$ are uniformly modulating functions and auto-power spectral density function of $x$ component of the tri-directional ground motions at the kth spatial support, respectively. $\rho_{k l x x}(\mathrm{i} \omega)$ is the coherence function for the $x$ component of ground motions between the kth and lth spatial supports.

The Clough-Penzien spectrum is used as the autopower spectral density functions for $S_{k k x x}(\mathrm{i} \omega), S_{k k y y}(\mathrm{i} \omega)$, and $S_{k k z z}(\mathrm{i} \omega)$, and are given by:

$$
S_{C P}(\omega)=\frac{1+4 \xi_{g}^{2}\left(\omega / \omega_{g}\right)^{2}}{\left[1-\left(\omega / \omega_{g}\right)^{2}\right]^{2}+4 \xi_{g}^{2}\left(\omega / \omega_{g}\right)^{2}} \cdot \frac{\omega^{4} \cdot S^{*}}{\left(\omega^{2}-\omega_{f}^{2}\right)^{2}+4 \xi_{f}^{2} \omega_{f}^{2} \omega^{2}}
$$

where $S^{*}$ is the constant spectral density of the whitenoise input, and $\omega_{g}, \xi_{g}, \omega_{f}$, and $\xi_{f}$ are the ground filter parameters. The proportion between amplitudes of power spectral density for tri-directional ground motions in $x, y$ and $z$ directions is $1: 0,72: 0,42$ [20]. The local site effect is assumed to be reflected in the input ground power spectral density model for the firm, medium, and soft site conditions, and the physical parameters of the power spectral density model for the three site conditions are given in Tab. 1 .
Table 1 Parameters of PSD functions of different soil type [21]

\begin{tabular}{|l|c|c|c|c|c|}
\hline \multicolumn{1}{|c|}{ Soil type } & $\omega_{g}(\mathrm{rad} / \mathrm{s})$ & $\xi_{\mathrm{g}}$ & $\omega_{f}(\mathrm{rad} / \mathrm{s})$ & $\xi_{f}$ & $\begin{array}{c}S^{*} \\
\left(\mathrm{~cm}^{2} / \mathrm{s}^{3}\right)\end{array}$ \\
\hline Firm (F) & 15,0 & 0,6 & 1,5 & 0,6 & 17,7 \\
\hline Medium (M) & 10,0 & 0,4 & 1,0 & 0,6 & 26,3 \\
\hline Soft (S) & 5,0 & 0,2 & 0,5 & 0,6 & 36,9 \\
\hline
\end{tabular}

The local site effect is reflected in the input power spectral density functions, and the power density curves corresponding to the three site conditions are shown in Fig. 1 using the site parameters given in Tab. 1.

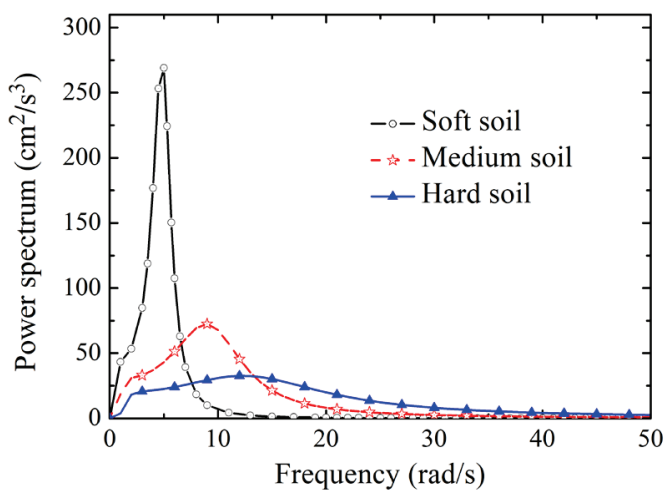

Figure 1 Power spectral density functions under different site conditions

The coherence function $\rho_{k l k x}(\mathrm{i} \omega)$ (or $\rho_{k l y y}(\mathrm{i} \omega)$ and $\left.\rho_{k l z z}(\mathrm{i} \omega)\right)$ in Eq. (9) can be written as:

$\rho_{k l}(i w)=\left|\rho_{k l}(i w)\right| \exp \left(-i w d_{k l}^{L} / v_{a p p}\right)$

where $\left|\rho_{k l}(i w)\right|$ denotes the lagged coherency representing the incoherence effect of spatially varying ground motions, $\exp \left(-i w d_{k l}^{L} / v_{a p p}\right)$ is the phase portion of $\rho_{k l}(i w)$ that represents the wave-path effect, $d_{k l}^{L}$ is the distance between spatial supports $\mathrm{k}$ and $\mathrm{l}$ along the wave propagation direction, and $v_{a p p}$ is the apparent wave velocity of seismic motions. In this paper, the lagged coherency model in Lin's paper [22] is used, which is given by:

$$
\left\{\begin{array}{c}
\left|\rho_{k l}(d, w)\right|=\mathrm{e}^{-a(\omega) \cdot d^{b(\omega)}} \\
a(\omega)=a_{1} \omega^{2}+a_{2} \\
b(\omega)=b_{1} \omega^{2}+b_{2}
\end{array}\right.
$$

where $a_{1}=0.1678 \times 10^{-4}, a_{2}=0.1219 \times 10^{-2}$. and $b_{2}=0.7674$.

Earthquake ground motions are non-stationary, because they initially grow from zero, and then have a steady phase, eventually decaying. Therefore, non-stationarity of earthquake ground motions should be taken into consideration. The uniformly modulated function in the time domain is widely used and has been adopted to model the non-stationarity of ground motions [21], which is given by:

$$
G(\mathrm{t})=\left\{\begin{array}{lr}
\left(t / t_{1}\right)^{2} & 0 \leq t \leq t_{1} \\
1 & t_{1} \leq t \leq t_{2} \\
e^{-c\left(t-t^{2}\right)} & t>t_{2}
\end{array}\right.
$$


where $t_{1}, t_{2}$ and $c$ are the shape-control parameters of the time modulating function, and they are given as $t_{1}=7.1 \mathrm{~s}$, $t_{2}=19.5 \mathrm{~s}$, and $c=0.16$ in this paper [22]. If $G(\mathrm{t})=1$, this will be a stationary stochastic process of earthquake excitations.

For the sake of simplicity, it is assumed that the modulating function at $\mathrm{x}, \mathrm{y}$, and $\mathrm{z}$ directions are the same.

Based on Eqs. (4) $\div(10)$, the power spectral density matrix of the tri-directional spatially varying ground motions in Eq. (3) can be constructed, which will be used in the following section to compute the input pseudoforces in the stochastic seismic analysis of structures using PEM. The power spectral density matrix $S_{0}(i w, t)$ of the tri-directional non-stationary spatially varying ground motions can be decomposed as:

$$
S_{0}(i w, t)=P^{*} \cdot P^{T}=[G(t)][V]\left[S_{C P}\right]\left\{q_{0}\right\} \cdot\left\{q_{0}\right\}^{T}\left[S_{C P}\right]^{T}[V]^{T}[G(t)]^{T}
$$

where $P$ is the pseudo-force matrix with dimensions $3 m \times r, r$ is the rank of matrix $S_{0}(i w, t)$, and superscripts * and $\mathrm{T}$ denote the complex conjugate and the transpose, respectively.

The vector of $\left[S_{C P}\right]$ has dimensions of $3 m \times 3 m$ given by:

$$
\begin{aligned}
& {\left[\sqrt{S_{C P}(\omega)}\right]=\operatorname{diag}\left[\sqrt{S_{C P 1 x}(\omega)}, \sqrt{S_{C P 1 y}(\omega)}, \sqrt{S_{C P 1 z}(\omega)}, \sqrt{S_{C P 2 x}(\omega)},\right.} \\
& \left.\sqrt{S_{C P 2 y}(\omega)}, \sqrt{S_{C P 2 z}(\omega)}, \cdots, \sqrt{S_{C P m x}(\omega)}, \sqrt{S_{C P m y}(\omega)}, \sqrt{S_{C P m z}(\omega)}\right]
\end{aligned}
$$

where $S_{C P m x}(\omega)$ denotes the power spectral density function at the $\mathrm{x}$ component of ground motions in the $m^{\text {th }}$ spatial support. $R$ is the lagged coherence matrix given by:

$$
[\mathrm{R}]=\left\{q_{0}\right\} \cdot\left\{q_{0}\right\}^{T}=\left[\begin{array}{cccc}
1 & \left|\rho_{12}\right| & \cdots & \left|\rho_{1 N}\right| \\
\left|\rho_{21}\right| & 1 & \cdots & \left|\rho_{2 N}\right| \\
\vdots & \vdots & \ddots & \vdots \\
\left|\rho_{N 1}\right| & \left|\rho_{N 2}\right| & \cdots & 1
\end{array}\right]
$$

where $N=3 m$, and $[\mathrm{R}]$ is a definite or semi-definite symmetric matrix. The rank of $[R]$ is greater than 1 and it can be decomposed as the summation of non-zero eigenvalues $\alpha_{j}$ and the corresponding normalized eigenvectors $\{\varphi\}_{j}(j=1,2, \cdots, r, r \leq 3 m)$, which are given by:

$$
[\mathrm{R}]=\sum_{j=1}^{r} \alpha_{j}\{\varphi\}_{j}^{*}\{\varphi\}_{j}^{T}
$$

The pseudo-excitations can be obtained based on the coherence level of the spatially varying ground motions, which are:

Fully coherent (all elements in matrix [R] are 1)

$$
P=[G(\mathrm{t})][V]\left\{q_{0}\right\} \sqrt{S_{C P}(\omega)} e^{i \omega t}
$$

Partially coherent (diagonal elements of matrix [R] are 1)

$$
P=[G(\mathrm{t})][V]\{\varphi\}_{j} \sqrt{\alpha_{j} S_{C P}(\omega)} e^{i \omega t}
$$

Completely incoherent (off-diagonal elements of matrix are 0 and the diagonal ones are 1)

$$
P=[G(\mathrm{t})][V] \sqrt{S_{C P}(\omega)} e^{i \omega t}
$$

After obtaining the pseudo-excitations at different coherence levels, the pseudo responses can then be derived

The pseudo response of absolute displacement with respect to the $j^{\text {th }}$ eigenvalue can be obtained by:

$\tilde{y}_{a j}=\sqrt{\alpha_{j} S_{C P}(\omega)} I_{j}(t), I_{j}(t)=\int_{0}^{t} h(t-\tau) G(\tau) \mathrm{V}\{\varphi\}_{j} e^{i \omega t} d \tau$

Then, the power spectral density of the pseudo response to placement under partially coherent tridirectional non-stationary ground motions can be expressed by substituting Eq. (18) into Eq. (2):

$S_{X_{s} X_{s}}(\omega, t)=\sum_{j=1}^{r} \tilde{y}_{a j}^{*} \tilde{y}_{a j}^{T} \sum_{j=1}^{r}=I_{j}^{*}(t) I_{j}^{T}(t) \alpha_{j} S_{C P}(\omega)$

\section{Numerical analysis \\ 3.1 The high-pier railway bridge and its finite element model}

To investigate the response of high-pier railway bridges under tri-directional stationary and non-stationary spatially varying ground motions, a long span, high-pier, continuous rigid frame bridge has been employed in this paper. The railway bridge has the total span of $466 \mathrm{~m}$ and consists of a left bridge system and a right bridge system. The left bridge portion is a pre-stressed concrete, continuous, rigid frame system with a layout of $88 \mathrm{~m}+$ $168 \mathrm{~m}+88 \mathrm{~m}$, while the right bridge is a pre-stressed concrete, continuous beam system with a layout of $33 \mathrm{~m}+$ $56 \mathrm{~m}+33 \mathrm{~m}$. The railway bridge piers are numbered from Pier \#1 to Pier \#5, and the highest pier, Pier \#2, has a height of $103 \mathrm{~m}$. Pier \#1 and Pier \#2 have hollow rectangular variable cross-sections, while the other piers have hollow oval variable cross-sections. These configurations are presented in the details in Fig. 2, together with a cross-section of the main girder.

The 3-D FE model of the high-pier railway bridge was built using ANSYS. The beam189 element was used to model the main girder and piers with variable crosssections. The mass 21 element was used to simulate the large masses that are attached to structural supports, and the calculated pseudo-excitations that are exerted on these large masses in the large mass method. The fixed boundary conditions were applied to the bottom of Pier \#1 to Pier \#5, and the vertical DoF (Z), transverse DoF (Y), and rotational DoFs with respect to $\mathrm{Z}$ (Rotz) and X (Rotx) directions were fixed both in the north and south abutments of this railway bridge. All the DoFs of Pier \#1, Pier \#2, and Pier \#4 were coupled with the corresponding DoFs of the main girder, while the longitudinal DoF (X) of Pier \#3, Pier \#5, and the main girder in their connection parts were released. The 3-D FE model of the high-pier railway bridge in the general finite element platform ANSYS is presented in Fig. 3. Using the initial FE model, 
modal analysis is conducted using the Block-Lanczos method. In ANSYS mode analysis, the previous five vibration mode frequencies are $0,73,0,93,1,23,1,36$ and $1,37 \mathrm{~Hz}$. All modes are assumed to have $5 \%$ damping.

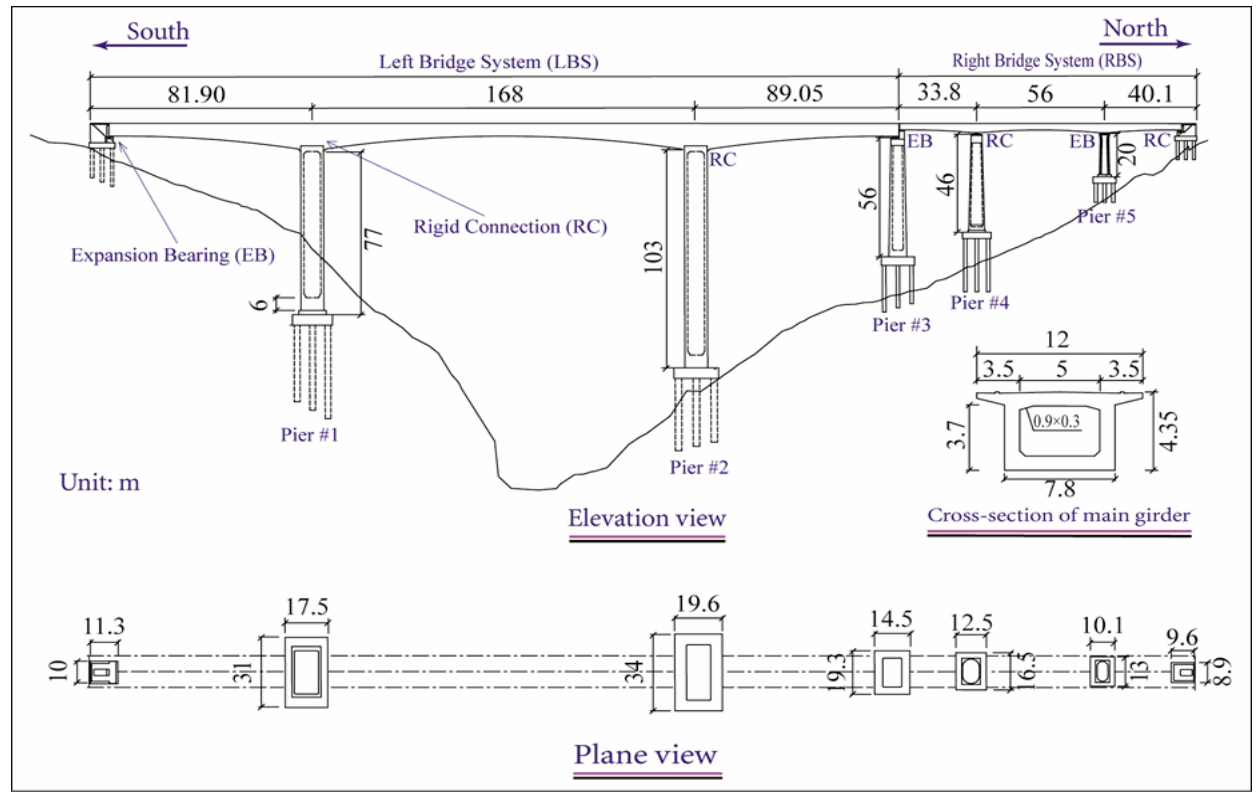

Figure 2 Schematic view of the high-pier railway bridge.

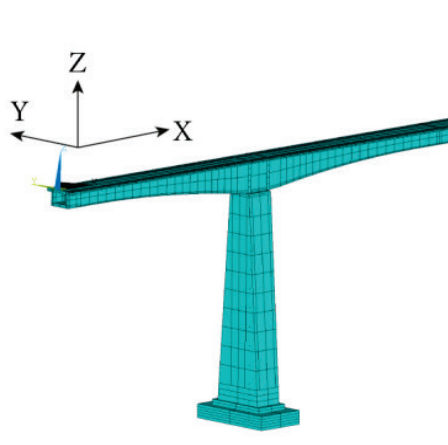

Pier \#1

Figure $3 \mathrm{FE}$ model of a high-pier railway bridge

Table 2 Analysis cases for non-stationary and stationary earthquake excitations under different sites.

\begin{tabular}{|c|c|c|c|}
\hline Case & NSE & Case & SE \\
\hline$\# 1$ & $v_{a p p}=\infty$ & $\# 4$ & $v_{a p p}=\infty$ \\
\hline$\# 2$ & $v_{a p p}=50 \mathrm{~m} / \mathrm{s}$ & $\# 5$ & $v_{a p p}=50 \mathrm{~m} / \mathrm{s}$ \\
\hline$\# 3$ & $v_{a p p}=500 \mathrm{~m} / \mathrm{s}$ & $\# 6$ & $v_{a p p}=500 \mathrm{~m} / \mathrm{s}$ \\
\hline$\# 7$ & PC & $\# 10$ & PC \\
\hline$\# 8$ & NC & $\# 11$ & NC \\
\hline$\# 9$ & FC & $\# 12$ & FC \\
\hline
\end{tabular}

$\left(v_{a p p}{ }^{-}\right.$Apparent velocity, especially, $v_{a p p}=\infty$ means uniform excitation, SE-stationary excitation, NSE-non-stationary excitation, FCfully coherent, PC- partially coherent, NC- non coherent) It should be noted that, due to the consideration of case 1 and case 4 , the coherent effects are considered fully coherent by default. So in this table, case 9 and case 12 , which are considered to be fully coherent, are equivalent to case 1 and case 4 .

\subsection{Analysis cases for stationary and non-stationary seismic excitations}

As previously mentioned, the basic site combination is one of the most unfavorable conditions possible, in which the highest pier is in soft ground conditions while the other piers are in firm conditions. Therefore, only incoherence effects and wave-passage effects should be concerns in this paper. Hence, the analytical cases are presented in Tab. 2 for non-stationary and stationary seismic analysis for twelve different conditions.

\section{Results \\ 4.1 Effect of wave-passage on structural response}

For the wave-passage effect on structural response, $v_{a p p}$ (apparent velocity) is a key index. According to the different values of the $v_{a p p}$, three cases of the wavespassage effect are presented in case \#1 to case \#6. For brevity, the structural responses, such as X-moment at the bottom of pier \#2, X-displacement of the main girder on pier \#2, X-shear force and Y-shear force at the bottom of pier \#2 have been reported because of the dominant role of Pier \#2 in structural seismic response. The 3-D power spectral density functions of structural responses under case \#1 are presented in Fig. 4. As expected, power spectral density functions of structural response exhibit time and frequency-varying characteristics, while the power spectral density of the structural response under stationary input is maintained as the constant. 

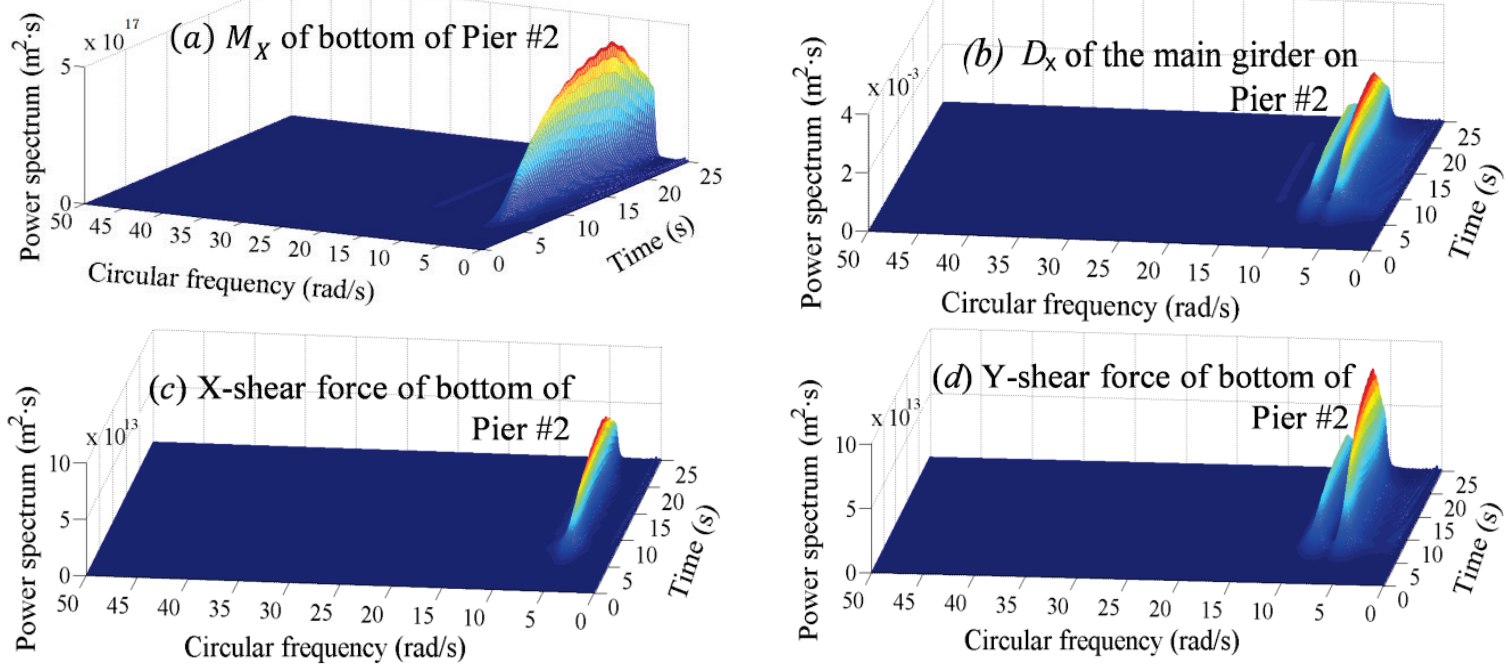

Figure 4 PSD functions of non-stationary structural responses under case 1 (uniform excitation)

a)

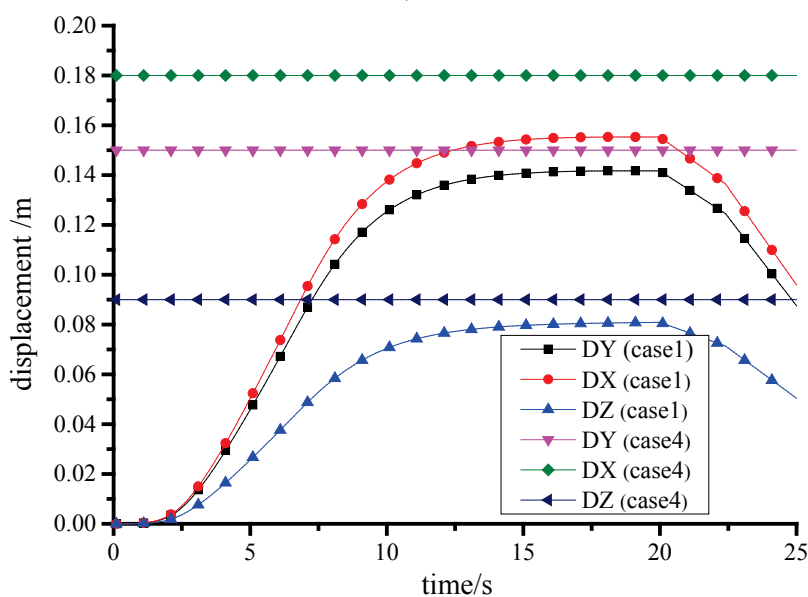

c)

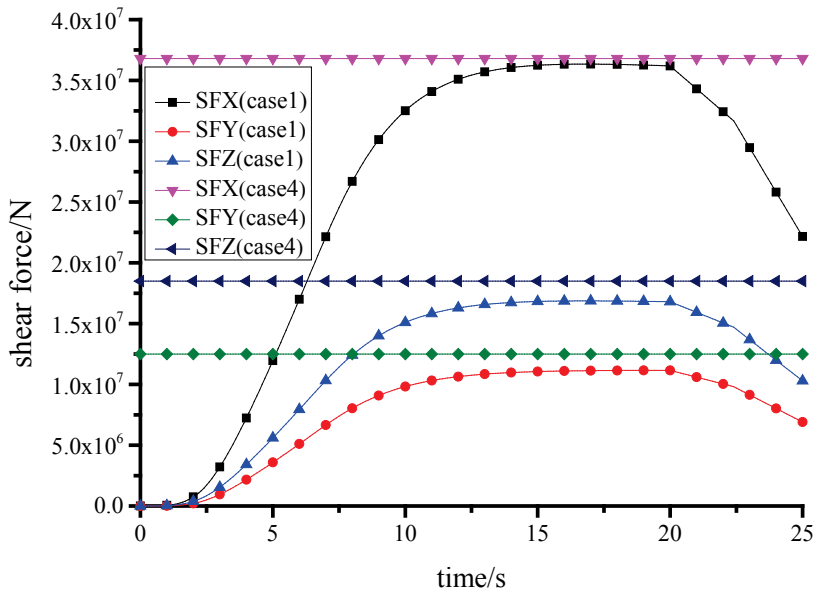

b)

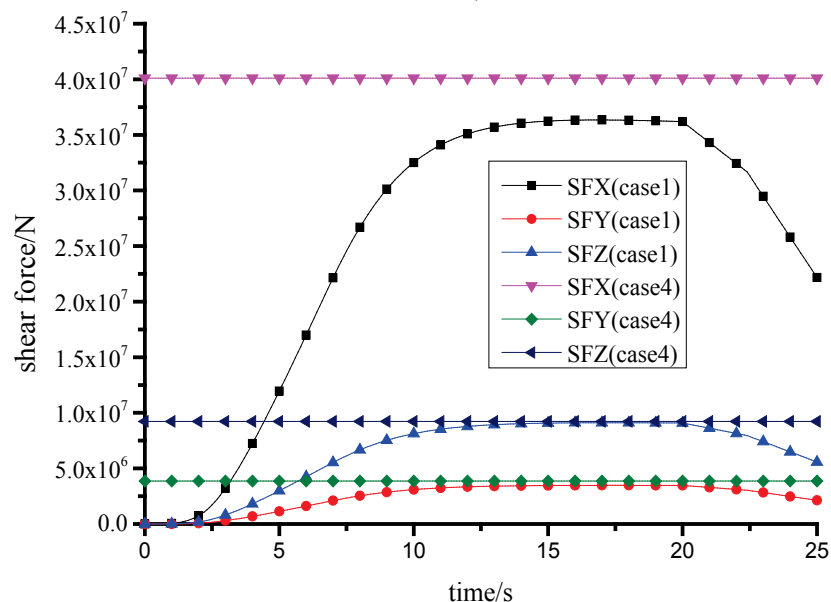

d)

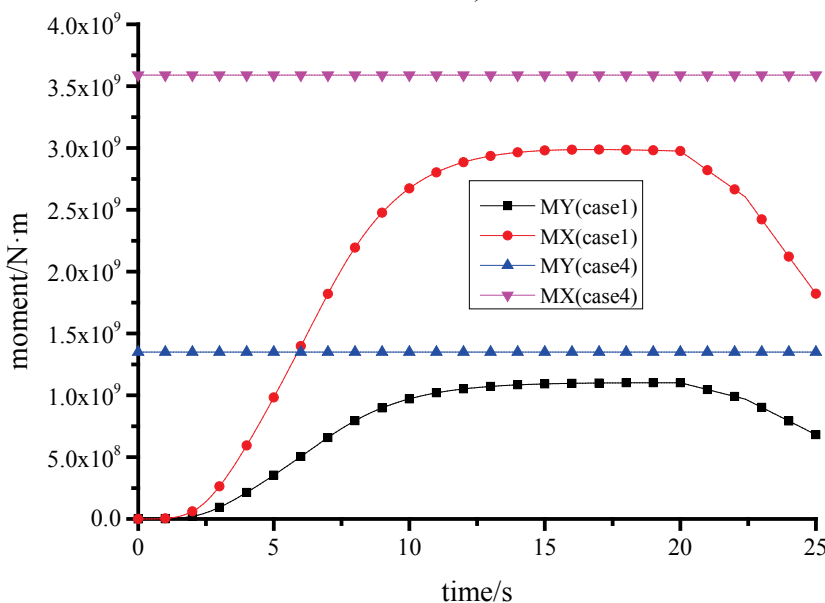

time/s

(a) The girder on pier \#2. (b) The girder on pier \#2. (c) The bottom of pier \#2. (d) The bottom of pier \#2.

Figure 5 Non-stationary structural responses and stationary structural responses at key positions of the bridge under case 1 and case 4

The time-dependent response variance (mean square deviation) $\sigma(t)$ is derived based on the obtained nonstationary power spectral density function of response $S_{X_{s} X_{s}}(\omega, t)$, by

$\sigma(t)=\sqrt{2 \int_{0}^{\infty} S_{X_{s} X_{s}}(\omega, t) \mathrm{d} \omega}$ in which the 3-D time dependent power spectral density function can be transformed into the 2-D time dependent response mean square deviation function; the response mean square deviation function was used for illustrations in the following instead of the above 3-D power spectral density function.

The seismic responses of structure under uniform excitation are as shown in Fig. 5, under non-stationary seismic excitation, the DX displacement of the main 
girder on the pier $2 \#$ is largest, DY follows, and DZ is minimum. Their maximum values are, respectively: 0,155 $\mathrm{m}, 0,142 \mathrm{~m}$, and $0,082 \mathrm{~m}$, which can be seen from Fig. 5a). Accordingly, under stationary seismic excitation, the three directional displacements of the main girder on Pier 2\# have the same rules as non-stationary excitation, and the values of DX, DY, DZ are as follows: $0,180 \mathrm{~m}, 0,151$ $\mathrm{m}, 0,092 \mathrm{~m}$. As can be seen, the displacement responses of the main girder on pier \#2 under stationary excitation are larger than for non-stationary excitation; the increases of displacements for the three directions $\mathrm{X}, \mathrm{Y}$ and $\mathrm{Z}$ are, respectively: $16,1 \%, 6,3 \%$, and $12,2 \%$. In Figs. $5 b), 5 c$ ), $5 \mathrm{~d})$, the shear force responses of the main girder in Pier $\# 2$, the shear force responses at the bottom of pier \#2 and the moment responses at the bottom of pier \#2 are presented as having the same variations as Fig. 5a). Clearly, $\mathrm{X}$ direction values are the maximum in each

a)

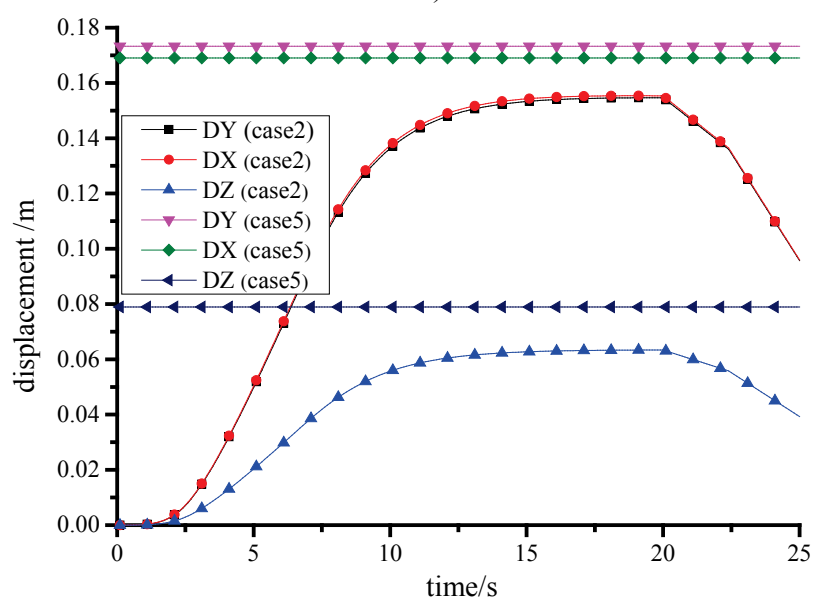

c)

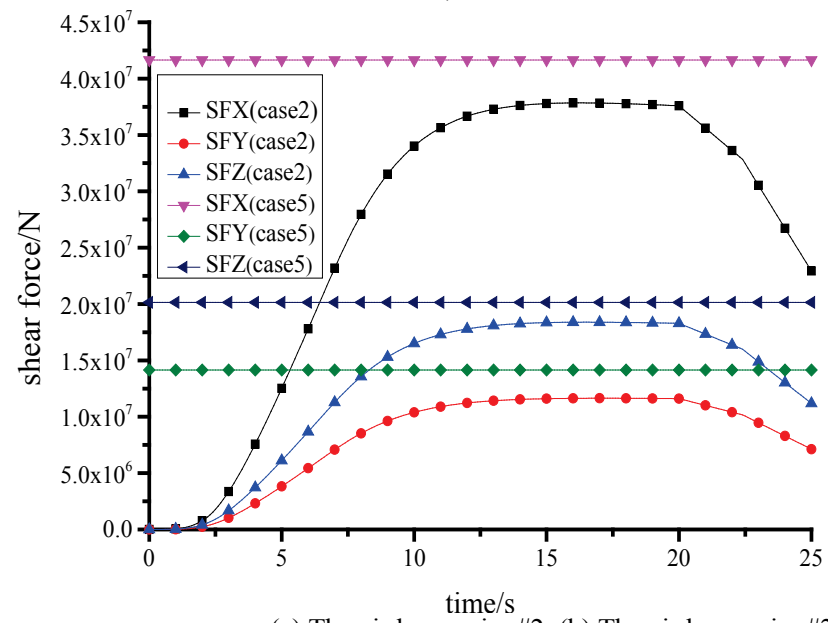

(a) The girder on pier \#2 (b) The girder on pier \#2. (c) The bottom of pier \#2. (d) The bottom of pier \#2.

Figure 6 Non-stationary structural responses and stationary structural responses at key positions of the bridge under case 2 and case 5

Figs. 7a) and 7b) present displacement responses of the main girder on Pier \#2 and moment responses at the bottom of Pier \#2, which take into consideration three cases regarding the values of apparent velocity. It can be seen from Fig. 7a), while giving different values of apparent velocity, the displacement responses of the main girder on Pier \#2 do not present a consistent variation. For the DX and DY responses, when the apparent velocity is $50 \mathrm{~m} / \mathrm{s}$, its values are at their maximum; the values follow when the apparent velocity is infinite, and the values are response, and the other two directions values are relatively small. Furthermore, stationary responses are larger than non-stationary responses, but because the increase is less than $20 \%$, it can be concluded that the largest increases appear in Fig. 5d), namely, the MY moment at the bottom of Pier 2\# increases $20 \%$ more under stationary excitations than non-stationary.

Fig. 6 shows the structural responses under nonstationary and stationary excitation when apparent velocities are $50 \mathrm{~m} / \mathrm{s}$. It is easy to see that Fig. 6 has similar variations as Fig. 5, while the size of each response value varies. Similarly, response values under stationary excitation are larger than those under nonstationary excitation. In Fig. 6, the maximum increases of two response values are the displacement DZ and shear force SFX of the main girder on Pier \#2, which are 24,5 $\%$ and $23,5 \%$, respectively.

b)

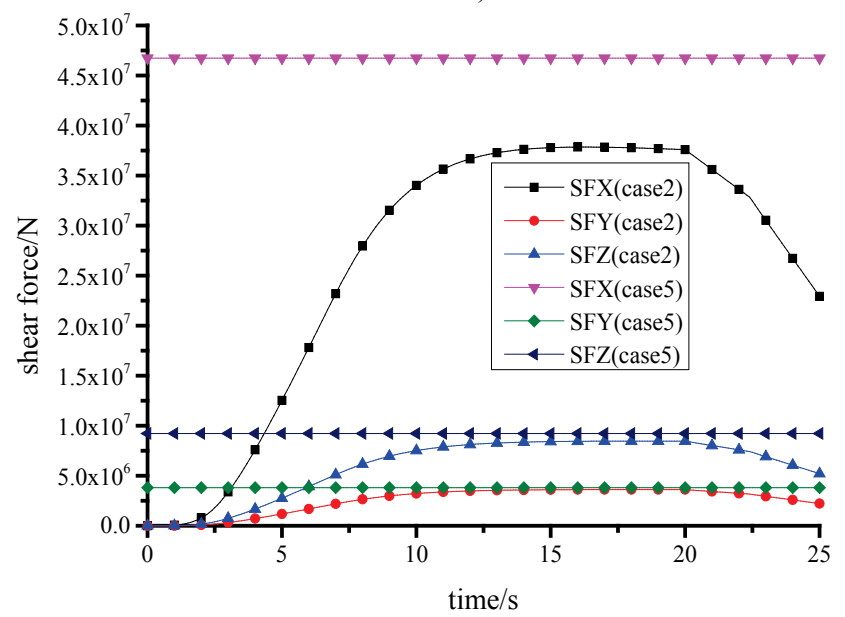

d)

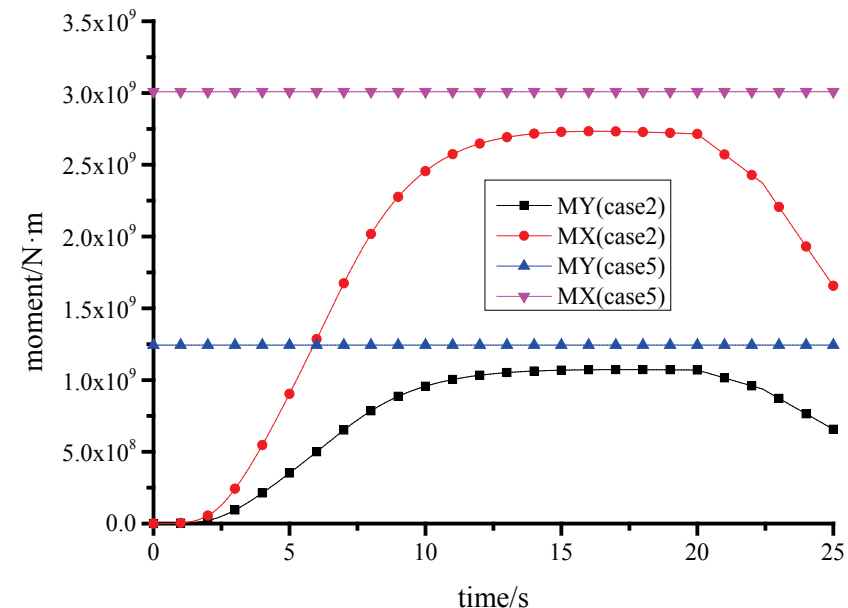
25

at their minimum when the apparent velocity is $500 \mathrm{~m} / \mathrm{s}$. But for DZ responses, its values are at their maximum when the apparent velocity is infinite, and when the apparent velocity is $50 \mathrm{~m} / \mathrm{s}$ and $500 \mathrm{~m} / \mathrm{s}$, its values are basically the same. In Fig. 7b), the moment responses MY and MX for the bottom of Pier \#2 have the same varying trend as the DX and DY responses in Fig. 7a). Therefore, the structural wave-passage effect has no consistent conclusion, which requires specific analysis. 


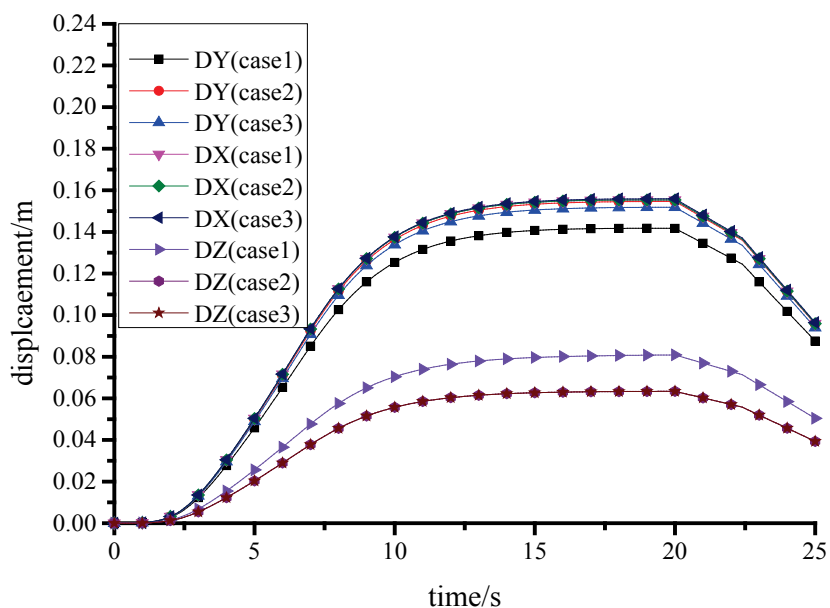

b)

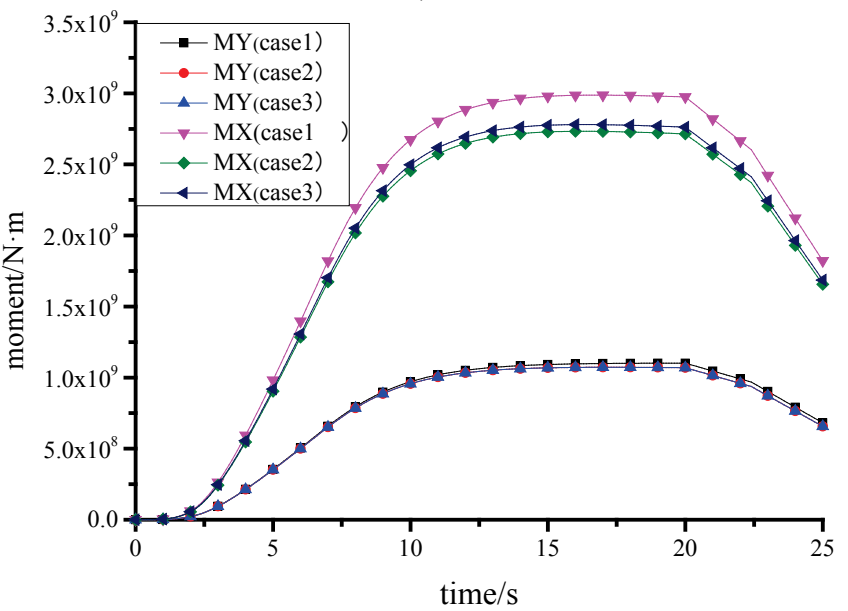

(a) The girder on pier \#2. (b) The bottom of pier \#2.

Figure 7 Non-stationary structural responses s at key positions of the bridge that considers the wave passage effect (case 1 , case 2 and case 3 )

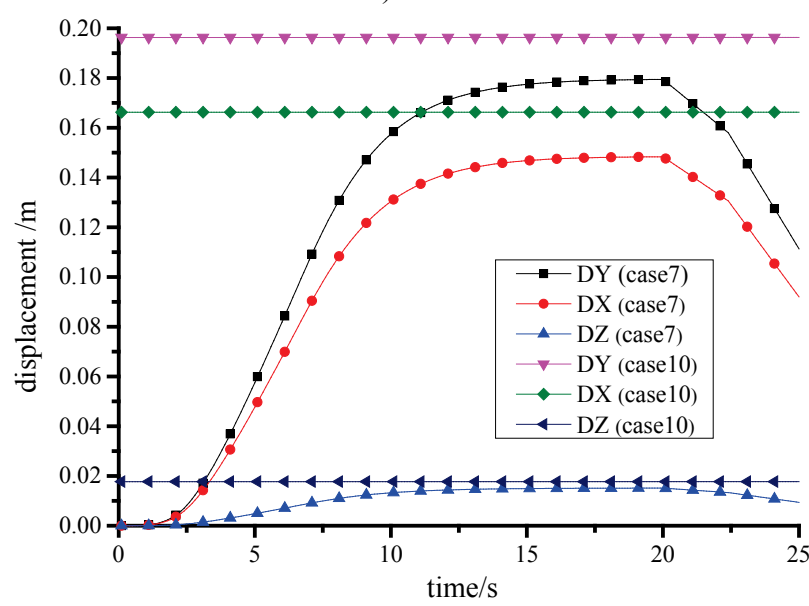

c)

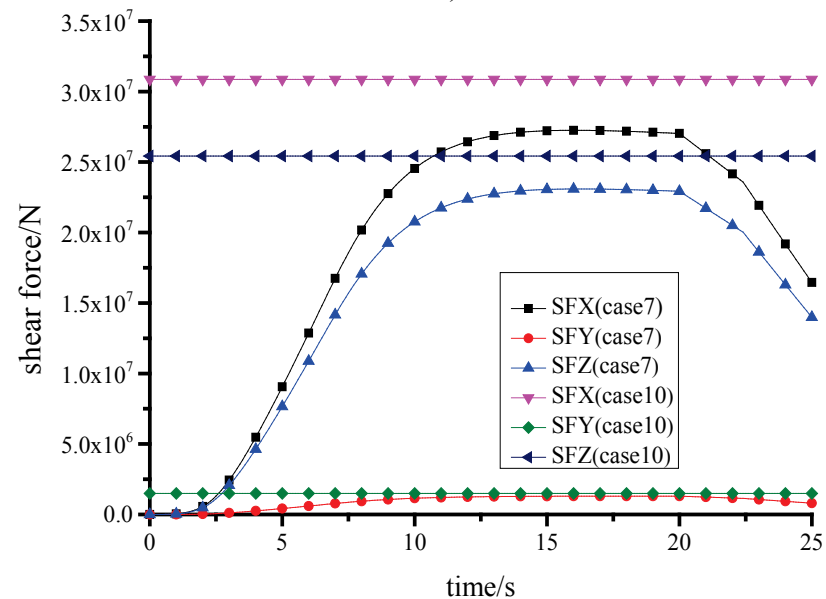

b)

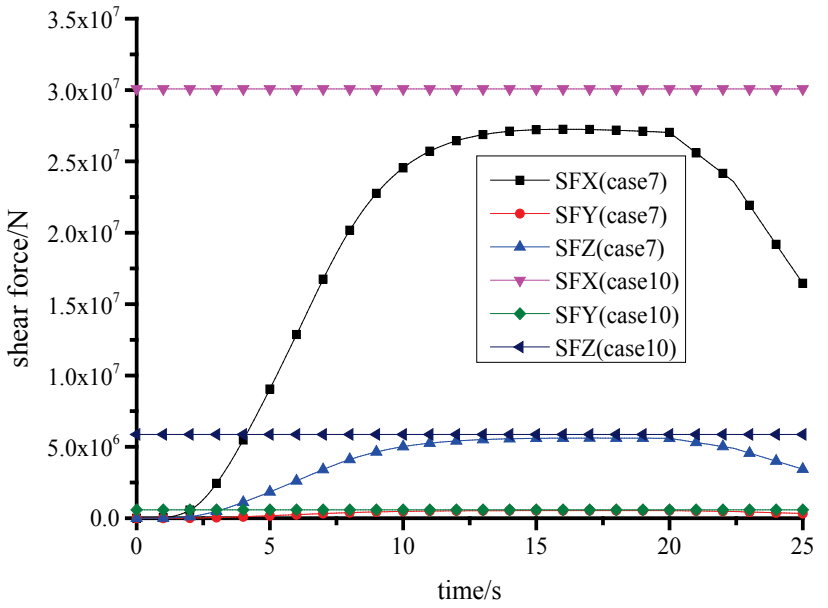

d)

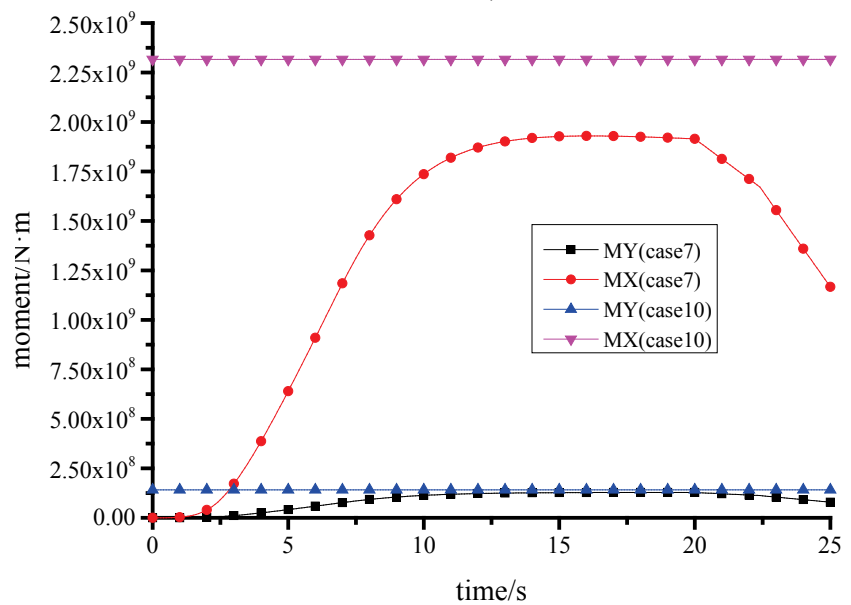

(a) The girder on pier \#2. (b) The girder on pier \#2. (c) The bottom of pier \#2. (d) The bottom of pier \#2.

Figure 8 Non-stationary structural responses and stationary structural responses at key positions of the bridge under case 7 and case 10

\subsection{Effect of incoherence on structural responses}

In this article, case 9 and case 12 , which are considered to be fully coherent, are equivalent to case 1 and case 4 . Due to space limitations, there is no longer a separate listing beyond that which is referred to in Fig. 5 . The responses of key positions that consider partially coherent effects are shown in Fig. 8, this can be seen from 8(a): the displacement DY of the main girder on Pier \#2 under non-stationary seismic excitations was largest, with DX following, and DZ as the minimum. Its maximum values, respectively: $0,179 \mathrm{~m}, 0,148 \mathrm{~m}$, and $0,015 \mathrm{~m}$. Accordingly, under stationary seismic excitation, the three directional displacements of the main girder on Pier \#2 also have the same rules as non-stationary excitation. DY, DX, and DZ increased in three directions: 9,3\%, $12 \%$, and $17,1 \%$, respectively. According to Figs. 8b), 8c), 8d), the shear force response of the main girder on pier \#2, the 
shear force responses at the bottom of pier \#2 and the moment responses at the bottom of pier \#2 are presented with the same variations as Fig. 8a). Clearly, X direction values are at their maximum in each response, while the other two direction values are relatively small. The stationary responses are larger than the non-stationary, but their increases were less than $15 \%$. Consequently, it can be concluded that the largest increases appear in Fig. 8c), namely the SFX shear force at the bottom of Pier \#2, which increased $14,8 \%$ under stationary excitations than non-stationary. a)

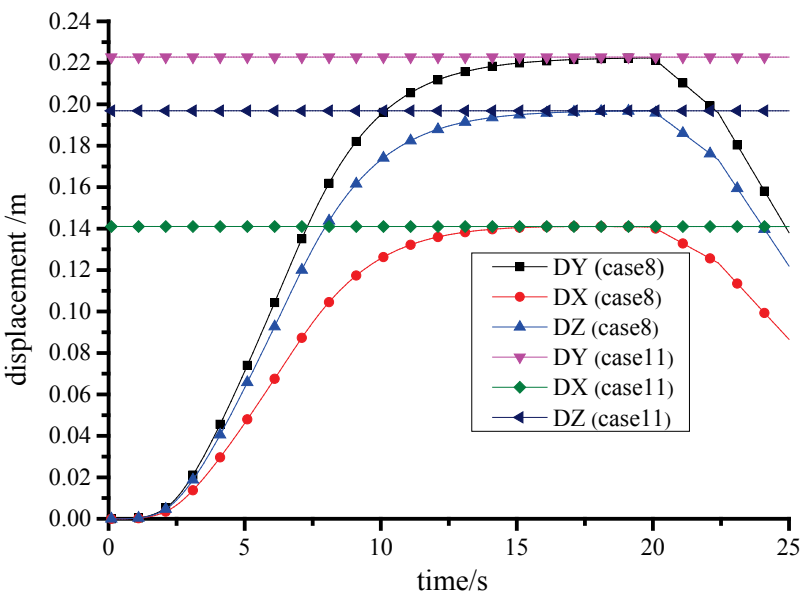

c)

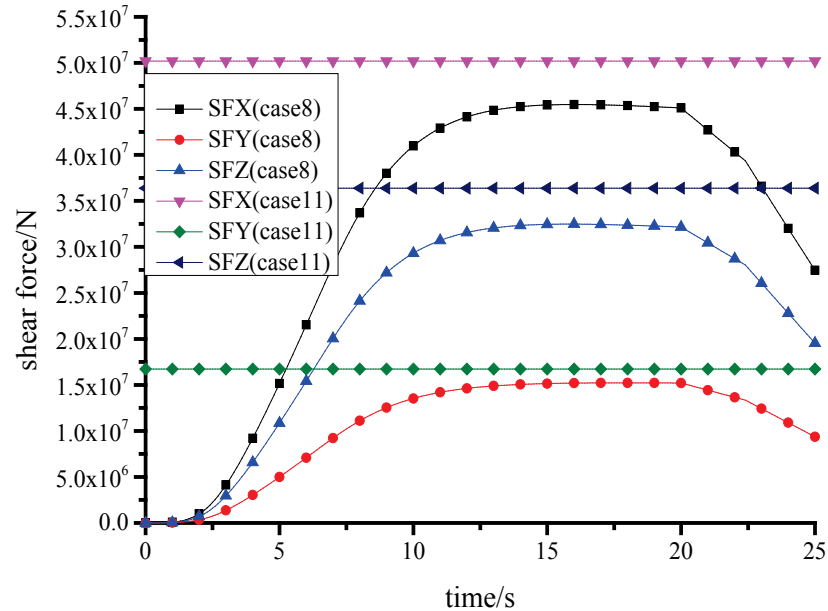

b)

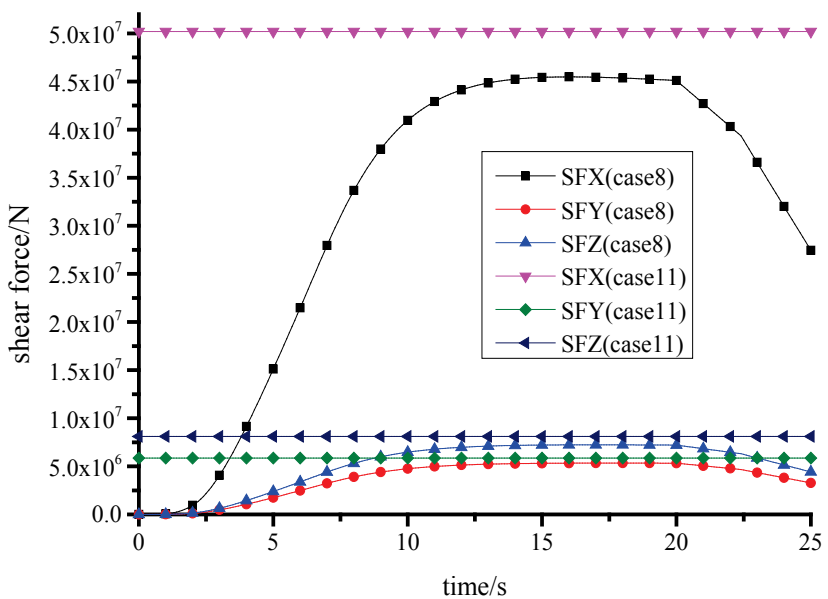

d)

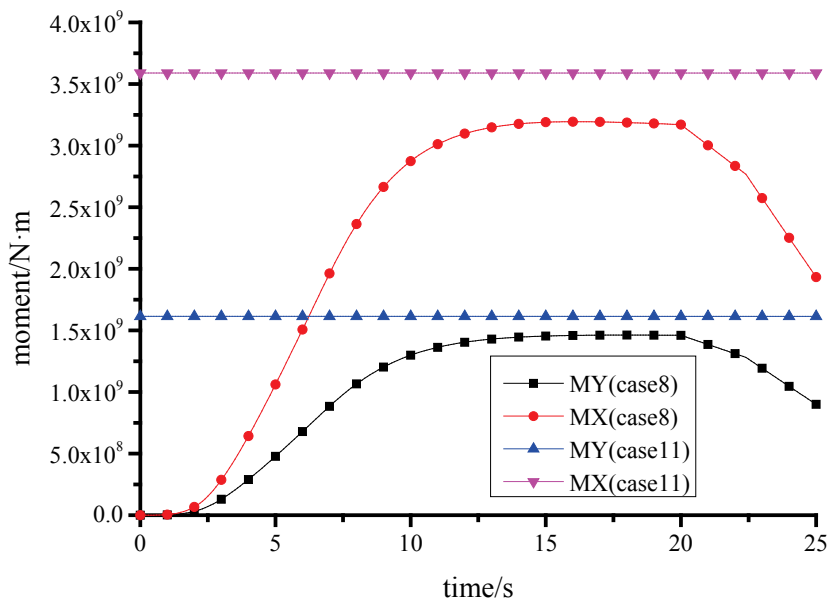

(a) The girder on pier \#2. (b) The girder on pier \#2. (c) The bottom of pier \#2. (d) The bottom of pier \#2.

Figure 9 Non-stationary structural responses and stationary structural responses at key positions of the bridge under case 8 and case 11

a)

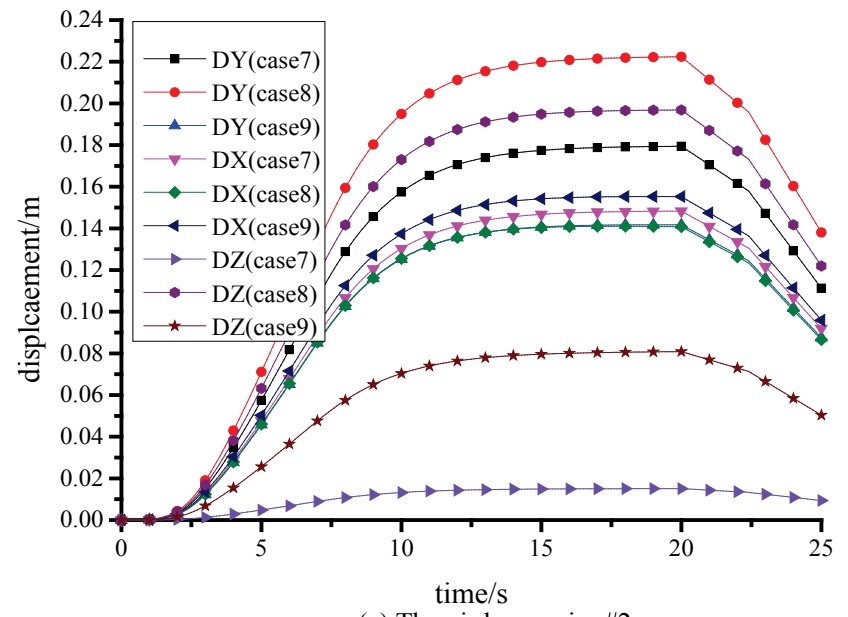

(a) The girder on pier \#2. b)

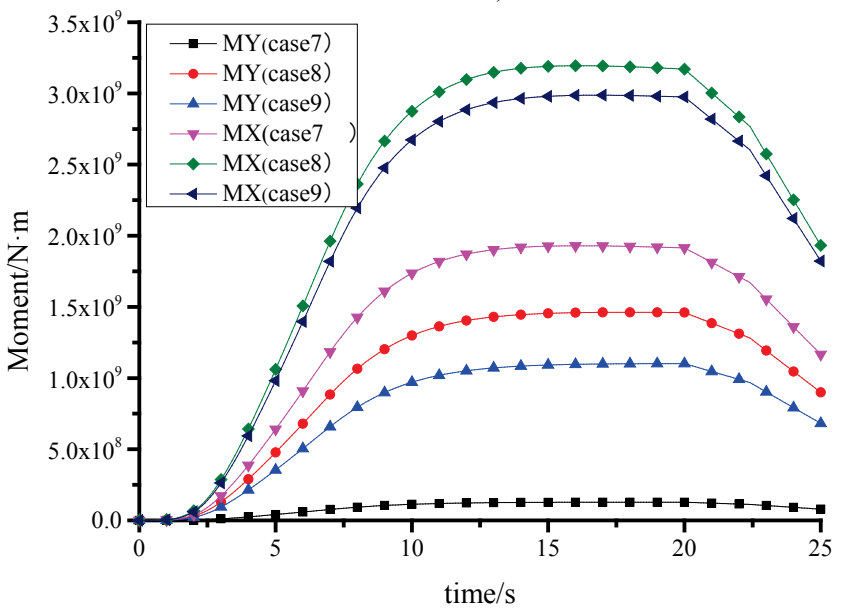

(b) The bottom of pier \#2.

Figure 10 Non-stationary structural responses at key positions of the bridge that consider the incoherent effect (case7, case 8 and case 9)

Fig. 9 shows the structural responses under nonstationary and stationary excitation with consideration to a non-coherent case. As is evident, Figs. 8 and 9 show a similar variation as Fig. 5, while varying the sizes of each 
response values. Compared with the fully coherent case in Fig. 5a), the displacement responses increased markedly. Similarly, the response values under stationary excitation are larger than under non-stationary excitation. In Fig. 9, responses of key positions under non-stationary and stationary excitations are close, in which increases are controlled within $15 \%$.

The displacement responses of the main girder on Pier \#2 and the moment responses from the bottom of Pier \#2 take into consideration three cases regarding the incoherence effect, presented in Figs. 10a) and 10b), respectively. Both can be seen in Figs. 10a) and 10b), and compared to the other two cases of incoherence effects, the displacement responses of the main girder on Pier \#2 and the moment responses from the bottom of Pier \#2 show significant improvement when non-coherent effects are considered. For example, in Fig. 10a), the displacement DY increased nearly $25 \%$ more than full coherence when the non-coherent effect was taken into consideration. Therefore, it can be concluded that when dealing with the large-span rigid frame bridges in mountainous areas, non-coherence conditions are the most unfavorable conditions in the analysis of incoherent effects, which requires attention in seismic design in the future.

\section{Conclusion}

This paper presented a theoretical analysis of a highpier railway bridge subjected to spatially varying stochastic stationary and non-stationary earthquake excitations using the pseudo-excitation method (PEM). Considering wave-passage effects and incoherence effects, the response values of the structural key positions under non-stationary and stationary excitation were analyzed and contrasted. Four conclusions drawn from this research can also be considered as specifications for the seismic design and analysis of a high-pier railway bridge with seismic design guidelines, which include:

(1) A comprehensive and systematic stochastic seismic analysis approach is derived for long span structures under tri-directional non-stationary and stationary spatial motions considering wave-passage effect and incoherence effect. This theoretical approach can be considered in seismic design guidelines for nonstationary and stationary stochastic seismic analysis of long-span structures.

(2) Either considering the wave-passage effect or incoherence effect, the responses of key positions in a structure under stationary excitation are larger than under non-stationary excitation. In other words, seismic responses from a structure under stationary excitation are overestimated. Through a comparative analysis in this paper, it was found that given the incentive values of structure responses under stationary excitation as opposed to non-stationary, its growth ratio was less than $25 \%$, which could be accepted in engineering. Therefore, a nonstationary stochastic analysis of high-pier railway bridges under tri-directional spatial ground motions can be simplified to a stationary random analysis to avoid excessive computation.

(3) When only the wave passage effect is concerned, the structural responses under non-stationary excitation with different apparent velocities do not show a particular rule. The structural responses change with apparent changes in velocity. Therefore, a wave-passage effect on the structure has no consistent conclusion, which should be analyzed.

(4) In instances where only the incoherence effect is concerned, when compared to the other two cases of the incoherence effect, the structural responses show significant improvement where the non-coherent effect is concerned. For a large-span rigid frame bridge in mountainous areas, non-coherence conditions are the most unfavorable conditions in this analysis of the incoherence effect, a matter that requires attention in seismic design in the future.

\section{Acknowledgements}

The study was supported by the National Science Foundation of China (No. 51308465, 51378443 and U1234208), Postdoctoral Science Foundation of China (No. 2015M580031) and the Fundamental Research Funds for the Central Universities (No. 2682014CX004EM).

\section{References}

[1] Wang. M.; Gan. K. The railway of the 21st Century. Tsinghua University Press, Beijing, 2011.

[2] Cheng C. T.; Yang J. C.; Ye Y. K.; Chen S. E. Seismic performance of repaired hollow-bridge piers. // Construction and Building Materials. 17, 5(2003), pp. 339351. DOI: 10.1016/S0950-0618(02)00119-8

[3] Wang Z. A. Preliminary report on the great Wenchuan earthquake. // Earthquake Engineering and Engineering Vibration. 7, 2(2008), pp. 225-234. DOI: 10.1007/s11803-0080856-1

[4] MRC. Code for seismic design of railway engineering: GB 50111-2006. Ministry of Railways of China, Beijing, 2006.

[5] Caglayan, O.; Ozakgul, K.; Tezer,O.; Ugider, E. Evaluation of a steel railway bridge for dynamic and seismic loads. // Journal of Constructional Steel Research. 67, 8(2011), pp. 1198-1211. DOI: 10.1016/j.jcsr.2011.02.013

[6] Liang, Z. Y. Study on seismic design theory of irregular girder bridge with high piers. $\mathrm{PhD}$ thesis, Tongji University, Shanghai, China, 2007.

[7] CEN. Eurocode 8: Design Provisions of Structures for Earthquake Resistance, Part 2: Bridges, EN1998-2:2005. European Committee for Standardization, Brussels, 2005.

[8] National Standard of the People's Republic of China. Code for Seismic Design of Buildings, GB 50011-2010. Chinese Architectural Industry Press, Beijing, 2010.

[9] Ministry of Communications of the People's Republic of China. Guidelines for Seismic Design of Highway Bridges, JTG/T B02-01-2008. China Communications Press, Beijing, 2008.

[10] Lin, J. H.; Zhang, Y. H.; Li, Q. S.; Williams, F. W. Seismic spatial effects for long-span bridges using the pseudo excitation method. // Engineering Structures. 26, 9(2004), pp. 1207-1216. DOI: 10.1016/j.engstruct.2004.03.019

[11] Jia, H. Y.; Zheng, S. X. Pseudo Excitation Method of Direct Solving Ground Motion Equation of MultiDimensional and Multi-Support Excitation. // Engineering Mechanics. 30, 3(2013), pp. 341-346. (in Chinese)

[12] Lin, J. H.; Zhang, W. S.; Williams,F.W; Pseudo-Excitation Algorithm for Non-Stionary Random seismic Response. // Engineering Structures. 19, 7(1997), pp. 586-593. DOI: 10.1016/S0141-0296(97)83154-9 
[13] Zheng, S. X.; Jia, H. Y.; Zhang, J.; Luo, N. Pseudo Excitation Method of Direct Solving Ground Motion Equation of Multi-Dimensional and Multi-Support NonStationary Excitation. // Engineering Mechanics. 31, 1(2013), pp. 85-90. (in Chinese)

[14] Kiueghian, A. D.; Neuenhofer, A. Response spectrum method for multi-support seismic excitations. // Earthquake Engineering \& Structural Dynamics. 21, 8(1992), pp. 713740. DOI: $10.1002 /$ eqe. 4290210805

[15] Konakli, K.; Kiureghian, A. D.; Stochastic Dynamic Analysis of Bridge Subjected to Spatially Varying Ground Motions. Department of Civil and Environment Engineering University of California, Berkeley. August, 2011.

[16] Jia H. Y.; Zhang, D. Y.; Zheng, S. X. Local Site Effects on a High-pier Railway Bridge under Tridirectional Spatial Excitations: Nonstationary Stochastic Analysis. // Soil Dynamics and Earthquake Engineering. 52, 1(2013), pp. 55-69. DOI: 10.1016/j.soildyn.2013.05.001

[17] Zhang, D. Y.; Jia, H. Y.; Zheng, S. X.; Xie, W. C.; Pandey, M. D. A highly efficient and accurate stochastic seismic analysis approach for structures under tridirectional nonstationary multiple excitations. // Computers \& Structures. 145, 3(2014), pp. 23-35. DOl: 10.1016/j.compstruc.2014.07.017

[18] Smeby, W.; Kiureghian, A. D. Modal combination rules for multi-component earthquake excitation. // Earthquake Engineering and Structural Dynamics. 13, 1(1985), pp. 112. DOI: $10.1002 /$ eqe. 4290130103

[19] Cao, Z.; Xue, S. Seismic analysis and design of spatial structures. Science Press, Beijing, 2006.

[20] Lin, J. H.; Zhang, Y.; Zhao, Y. Seismic spatial effects on dynamic response of long-span bridges in stationary inhomogeneous random fields. // Earthquake Engineering and Engineering Vibration. 3, 2(2004), pp. 171-180. DOI: 10.1007/BF02858232

[21] Jennings, P.; Housner, G.; Tsai, N. Simulated earthquake motions. Technical Report, Earthquake Engineering Research Laboratory, California Institute of Technology, 1968.

[22] Lin, J. H.; Zhao, Y.; Zhang Y. Accurate and highly efficient algorithms for structural stationary/non-stationary random responses. // Computer Methods in Applied Mechanics and Engineering. 191, 1(2001), pp. 103-111. DOI: 10.1016/S0045-7825(01)00247-X

\section{Authors' addresses}

\section{Jin Zhang, Ph.D.}

School of Civil Engineering, Southwest Jiaotong University, No. 111, North 1st Section of Second Ring Road, Jinniu District, 610031, Chengdu City, Sichuan Province, China E-mail: jin_zhang@my.swjtu.edu.cn

Hongyu Jia, Ph.D. (Corresponding author) Department of Civil Engineering, Southwest Jiaotong University, Emei Campus, No. 1, Jingqu road, 614202 Emei, Sichuan Province, China

College of Architecture \& Civil Engineering,

Beijing University of Technology, 100124, Beijing, China

E-mail: hongyu_swjtu@home.swjtu.edu.cn

\section{Shixiong Zheng, Ph.D., Professor}

School of Civil Engineering, Southwest Jiaotong University,

No. 111, North 1st Section of Second Ring Road, Jinniu District, 610031 Chengdu City, Sichuan Province, China

E-mail: zhengsx@home.swjtu.edu.cn

\section{Shiqiang Qin, Ph.D.}

School of Civil Engineering And Architecture,

Wuhan University of Technology,
No. 122, Luoshi road, 430070 Wuhan, Hubei Province, China E-mail: qsqiang417@126.com

Keyue Zhang, Ph.D., Professor

Department of Civil Engineering, Southwest Jiaotong University, Emei Campus, No. 1, Jingqu road, 614202 Emei, Sichuan Province, China

E-mail: zhangkeyue@163.com 